Jurnal Intelektualita: Keislaman, Sosial, dan Sains

Vol. 9 No. 2 (2020)

DOI: https://doi.org/10.19109/intelektualita.v9i2.6637

Copyright @ 2020 M. Fachry Zaiman, Nilawati, Nurfala Safitri

\title{
Optimalisasi Wakaf dalam Mengembangkan Pariwisata Halal di Kampung Al-Munawar
}

\author{
M. Fachry Zaiman ${ }^{1 *}$, Nilawati ${ }^{1}$, Nurfala Safitri $^{1}$ \\ ${ }^{1}$ UIN Raden Fatah Palembang, Indonesia
}

\begin{abstract}
Abstrak: Potensi pariwisata yang sangat besar menjadi perhatian pemerintah dalam upaya membangkitkan perekonomian Indonesia seperti Wisata Halal. Wakaf sebagai pemberdayaan harta benda dalam Islam berpotensi untuk mengembangkan perekonomian masyarakat melalui Wisata Halal. Wisata Halal Kampung Al-Munawar Palembang merupakan salah satu contoh objek wisata halal yang bersumber dari kegiatan wakaf di sekitar masyarakat. Penelitian ini bertujuan untuk mengetahui strategi Optimalisasi Wakaf dalam Pengembangan Wisata Halal di Desa Al-Munawar Palembang. Hasil penelitian menunjukkan perlunya strategi seperti meningkatkan kesadaran masyarakat untuk mewakili, meningkatkan kualitas sumber daya nazhir yang profesional dan kompeten, menjadikan wakaf sebagai pendukung Wisata Halal, dan menjadikan pelaku UMKM yang telah mendapat bantuan dana wakaf (mauquf). 'alaih) sebagai pemberi wakaf (waqif).
\end{abstract}

Kata Kunci: optimalisasi, wakaf, pengembangan, wisata halal

\begin{abstract}
The huge tourism potential has become the government's attention in an effort to revive the Indonesian economy such as Halal Tourism. Waqf as empowerment of property in Islam has the potential to develop the economy of the community through Halal Tourism. Halal Tourism Kampung Al-Munawar Palembang is one example of halal tourism objects that come from waqf activities around the community. This study aims to determine the strategy of Waqf Optimization in Developing Halal Tourism in Al-Munawar Village in Palembang. The results of the study indicate the need for strategies such as raising public awareness to represent, increasing the quality of professional and competent Nazhir resources, making waqf as a supporter of Halal Tourism, and making MSME practitioners who have received assistance from wakaf funds (mauquf 'alaih) as providers of waqaf (waqif).
\end{abstract}

Keywords: optimalization, waqf, developing, halal tourism

\section{Pendahuluan}

Indonesia dengan sumber daya alam yang begitu besar memiliki potensi untuk dijadikan sebagai sektor pariwisata yang akan berimplikasi terhadap peningkatan devisa negara. Pada tahun 2014 sekitar US \$10 miliar devisa negara berasal dari industri pariwisata. Tingginya potensi pariwisata harus dimanfaatkan dengan sebaikbaiknya untuk kesejahteraan rakyat.

Dalam mengembangkan pariwisata perlu keberadaaan destinasi wisata dengan memperhatikan 3A (Attractive, Amenities, dan Accessibilities). Di samping itu keberadaan wisata yang berbasis kultural yang sesuai dengan kondisi

\footnotetext{
${ }^{*}$ Corresponding Author: M. Fahcry Zaiman (zaimannoir@gmail.com). UIN Raden Fatah Palembang, Indonesia
} 
dan status masyarakat dapat meningkatkan brand kepariwisataan.

Berkaitan dengan kultural Indonesia, Indonesia yang bukan sebagai negara Islam namun memiliki jumlah penduduk muslim terbesar menjadi ciri khas tersendiri yang berkaitan dengan syariah Islam. Penguatan pondasi kultur Islam serta dijadikannya sebagai ciri khas dari Indonesia dapat menjadi daya jual dan daya tarik tersendiri melalui pengembangan sektor pariwisata. Salah satu upaya pemanfaatkan keunikan Indonesia dalam hal ini kultur Islam yang dapat dilakukan adalah dengan membuat kawasan sektor Pariwisata Halal. Selain itu, Vice President, Market Development, Mastercard Davesh Kuwedekar menambahkan, pasar perjalanan halal senantiasa menjadi salah satu segmen perjalanan yang bertumbuh paling cepat secara global. Ia pun mencatat, wisatawan muslim yang mewakili sekitar $10 \%$ dari keseluruhan industri perjalanan global sepanjang 2017 (Katadata.co.id, Desy Setyowati, 2019)

Tingginya jumlah wisatawan berimbas pada belanja wisata, mulai dari pembelian tiket pesawat, penginapan, dan akomodasi lain yang mencapai US\$ 177 miliar atau sekitar Rp 2.500 triliun pada 2017. Jumlah itu diperkirakan melonjak hingga US\$ 300 miliar atau sekitar Rp 4.200 triliun pada 2026. (Katadata.co.id, Tim Redaksi, 2019). Namun, perencanaan sektor Pariwisata secara umum masih mengalami permasalahan yang meliputi fasilitas yang ada di lokasi destinasi wisata seperti lokasi yang tidak begitu menarik dan akses untuk ke lokasi yang sangat sulit untuk dicapai.

Dalam konsep pariwisata halal, penerapan nilai ekonomi Islam menjadi ruh utama dalam pelaksanaan pariwisata halal. Salah satu instrumen keuangan berdasarkan ekonomi Islam adalah wakaf yang memiliki potensi besar untuk menghimpun dana dari masyarakat untuk mengatasi kelesuan ekonomi. Hal ini diperkuat dengan pernyataan Imam Teguh Saptono, selaku Presiden Direktur Global Wakaf Corporation bahwa Wakaf adalah pilar kekuatan ekonomi umat yang harus kembali ditegakkan. Kalau zakat itu kan 2,5 persen, berarti yang 97,5 persen itu potensi wakaf." (Imam Teguh Saptono, 2019)

Selain itu, jumlah penduduk Indonesia dengan mayoritas umat muslim mejadi salah satu faktor pendukung atas pelaksaan wakaf yang dapat dimanfaatkan untuk mengembangkan sektor pariwisata halal walaupun untuk realisasi wakaf sendiri belum mencapai target.

Dari hasil studi Universitas Islam Negeri Syarif Hidayatullah Jakarta pada tahun 2006, menunjukkan bahwa harta wakaf di Indonesia secara nasional yang terdata mencapai hampir 363 ribu bidang tanah, dengan nilai secara nominal diperkirakan mencapai Rp 590 triliun. Ini setara dengan lebih dari 67 milyar dolar AS jika kurs Rp 9.250/dolar. Jumlah ini tentu saja sangat besar. Andai saja seluruh harta wakaf ini dijual, hasilnya dapat menutupi $100 \%$ total utang luar negeri Pemerintah Republik Indonesia tahun 2008, yang besarnya "cuma" 60 milyar dolar AS. Ini sekedar untuk mudah memahami betapa besarnya harta wakaf. Dalam konteks lain, bandingkan nilainya yang setara dengan sekitar $85 \%$ APBN RI tahun 2009, yang besarnya sekitar Rp 700 triliun/tahun (Devi Megawati, 2014).

Provinsi Sumatera Selatan merupakan pusat kerajaan Sriwijaya yang juga terkenal dengan kerajaan maritim terbesar dan terkuat di Nusantara pada abad ke-7 hingga abad ke-12 Masehi. (BPKP, 2019) Salah satu kota di Sumatera Selatan adalah kota Palembang. Kota Palembang memiliki beberapa objek Pariwisata. Salah satunya adalah Kampung Al-Munawar yang disebut juga dengan Kampung Arab. Kampung Arab Al-Munawar di 
Palembang memiliki karakter tersendiri yang menunjukkan identitasnya. Sebuah mushalla yang berada di bagian utara kampung merupakan main entrance bagi lingkungannya karena berada di tepi Sungai Musi yang pada saat itu merupakan jalur transportasi utama bagi masyarakat di kota Palembang. Beberapa rumah terletak membujur timur-barat dengan orientasi menghadap arah utara dan selatan mengelilingi ruang terbuka. Jaringan sirkulasi jalan yang sempit dan jalan cul-de-sac yang terhubung ke jalan utama membentuk grid yang kurang sempurna (Aditha Maharani Ratna, 2019).

Selain itu, keberadaan Kampung AlMunawar sebagai salah satu objek Pariwisata Halal tidak terlepas dari adat istiadat yang berkaitan dengan syariat Islam di sektor ekonomi syariah melalui pemberdayaan harta masyarakat di lingkungan sekitar. Keberdaaan kampung almunawar dapat dijadikan sebagi contoh adanya kemajuan sebuah peradaban umat manusia berupa peninggalan fisik sebagai bukti kemajuan dalam segala aspek kehidupan melalui pengoptimalisasian wakaf. Wakaf sebagai salah satu instrumen keuangan Islam memiliki potensi dalam mengembangkan pariwisata halal. Hal ini terbukti dengan keberadaan Kampung Al-Munawar yang berasal dari kerelaan masyarakat dilingkungan sekitar agar Kampung Al-Munawar sebagai Objek Pariwisata Halal yang memiliki kesamaan dengan mekanisme wakaf.

\section{Hasil Penelitian dan Pembahasan}

\section{Latar Belakang dijadikannya Kampung Al- Munawar sebagai Objek Pariwisata Halal}

Berdasarkan pernyataan Muhammad selaku Kepala Kampung Al-Munawar bahwa dijadikannya Kampung Al-Munawar sebagai objek pariwisata pada tahun 2015 sebagai bentuk menyukseskan ASEAN Games, kampung AlMunawar memiliki beberapa kegiatan religi yang menjadi faktor dijadikannya kampung AlMunawar sebagai objek Pariwisata Halal sehingga pada tahun 2018 Kampung Al-Munawar dijadikan sebagai tempat wisata religi yang lebih dikenal sebagai pariwisata halal oleh Dinas Pariwisata dan Kebudayaan Provinsi Sumatera Selatan.

Dalam penetapannya banyak pihak yang terlibat dalam pembentukan Kampung AlMunawar sebagai Kampung Pariwisata seperti Dinas Pariwisata dan Kebudayaan Provinsi Sumatera Selatan, Pemerintah Provinsi, Pemerintah Kota, Perangkat Kecamatan, Perangkat Kelurahan, Perangkat Kampung dan tetua adat Kampung AlMunawar serta masyarakat di Kampung AlMunawar.

Muhammad juga menambahkan bahwa dijadikannya kampung Al-Munawar sebagai tempat pariwisata halal tidak terlepas atas kerelaan masyarakat dalam merelakan tempat tinggal mereka sebagai tempat pariwisata halal yang dapat dikunjungi oleh banyak orang selama tidak terlepas dari ketentuan norma-norma agama Islam dan sosial di lingkungan masyarakat. Selain kerelaan dari masyarakat sekitar, berdirinya kampung AlMunawar sebagai kampung pariwisata juga tidak terlepas dari keterlibatan pemerintah provinsi Sumatera Selatan dalam pendanaan serta adimistrasinya.

Terbentuknya sebagai pariwisata halal menjadi salah satu peluang masyarakat kampung Al-Munawar dalam mendapatkan sumber mata pencaharian masyarakat dilingkungan tersebut. Hal ini dikarenakan adanya status kampung $\mathrm{Al}$ Munawar sebagai kampung pariwisata. 
Strategi Optimalisasi Wakaf dalam Mengembangkan Pariwisata Halal di Kampung Al-Munawar

Dalam upaya pengoptimalisasian wakaf perlu adanya penegelolaan wakaf yang baik dan benar. Pihak yang paling berperan dalam pemanfaatan harta wakaf adalah Nazhir wakaf sebagai seseorang atau kelompok orang dan badan hukum yang diserahi tugas oleh wakif (orang yang mewakafkan harta) untuk mengelola wakaf dengan tujuan wakaf dapat menghasilkan manfaat dari hasil harta wakaf (Direktorat Pemberdayaan Wakaf, 2007).

Salah satu objek wakaf yang bisa dikelolah oleh Nazhir adalah dalam bentuk tanah. Kemampuan mengolah tanah yang minim dikarena faktor letak yang tidak strategis secara ekonomi dan kondisi tanah yang gersang, hambatan yang cukup mencolok untuk mengolah tanah wakaf secara produktif adalah kemampuan Sumber Daya Manusia (SDM), kondisi ini banyak di alami oleh para Nazhir wakaf yang ada di pedesaan di hampir seluruh pelosok nusantara, bahwa kemampuan menggarap masih sangat minim (Direktorat Pemberdayaan Wakaf, 2007).
Hal ini tidak Jauh berbeda dengan keadaan di Kampung Al-Munawar. Jika dilihat berdasarkan keadaan Alam di Kampung Al-Munawar, Kampung Al-Munawar tidak memiliki kelebihan dari daerah yang lainnya, hanya saja Sumber Daya Manusia (SDM) yang berada di Kampung AlMunawar memiliki nilai tambah karena dilatar belakangi oleh keturunan dan suku yang mereka miliki yaitu Arab. Hal ini pun berdampak pada kegiatan keagaman yang dilakukan oleh masyarakat sekitar seperti adanya pengajian di setiap malam hari, adat pernikahan dan kesenian seperti tari sufi yang masih kental dengan daerah timur tengah sehingga menjadi ciri khas tersendiri dari kampung Al-Munawar. Maka adanya nilai tambah dari kampung tersebut menjadi daya jual dari kampung Al-Munawar sebagai objek wisata.

Berdasarkan pernyataan tersebut bahwa kurangnya pemahaman dari masyarakat mengenai wakaf sehingga menyebabkan eksistensi dari wakaf tidak bisa dikenal oleh masyarakat walaupun telah ada kegiatan yang menyerupai wakaf. Oleh karena itu untuk mengoptimalkan wakaf di Kampung AlMunawar ada bebrapa hal yang harus dilakukan, seperti berikut:

Tabel 1 Strategi Optimalisasi Wakaf dalam

Mengembangkan Pariwisata Halal di Kampung Al-Munawar

\begin{tabular}{|c|c|c|}
\hline Program & Aktivitas & Tujuan \\
\hline \multirow[t]{2}{*}{$\begin{array}{l}\text { 1. Peningkatan kesadaran } \\
\text { masyarakat untuk } \\
\text { berwakaf }\end{array}$} & $\begin{array}{l}\text { 1.1. Melakukan sosialisasi dan gerakan } \\
\text { bersama secara intensif. } \\
\text { 1) Memasukkan materi wakaf dalam } \\
\text { khutbah Jum'at dilingkungan sekitar } \\
\text { yang wajib disampaikan oleh khotib. } \\
\text { 2) Memanfaatkan masjid sebagai sentral } \\
\text { sosialisasi pada tingkat komunitas } \\
\text { dengan mendorong masjid untuk aktif } \\
\text { mensyiarkan topik wakaf. }\end{array}$ & \multirow[t]{2}{*}{\begin{tabular}{ll} 
1. & \multicolumn{2}{l}{ Tersampaikannya } \\
materi wakaf dalam \\
khutbah \\
dilingkungan Jum'at \\
yang wajib disampaikan \\
oleh khotib. \\
2. Masyarakat memahami \\
dan menjalankan wakaf. \\
3. Masyarakat dapat \\
melakukan wakaf \\
dimanapun, kapanpun,
\end{tabular}} \\
\hline & $\begin{array}{l}\text { 1.2. Menggencarkan promosi wakaf melalui } \\
\text { berbagai media. }\end{array}$ & \\
\hline
\end{tabular}




\begin{tabular}{|c|c|c|c|}
\hline & $\begin{array}{l}\text { 1) Membuat kampanye massal gerakan } \\
\text { wakaf uang melalui media iklan yang } \\
\text { mendekati generasi milenial. } \\
\text { 2) Memanfaatkan Media dan Rekreasi } \\
\text { Halal untuk sarana promosi wakaf } \\
\text { guna mengembangkan pariwisata } \\
\text { halal di Kampung Al-Munawar. }\end{array}$ & \multirow[t]{2}{*}{$\begin{array}{l}\text { walaupun dalam jumlah } \\
\text { yang kecil. } \\
\text { Masyarakat lebih } \\
\text { mengenal Badan Wakaf } \\
\text { Indonesia (BWI). }\end{array}$} \\
\hline & & $\begin{array}{l}\text { 1.3. Melakukan gerakan bersama dalam } \\
\text { wakaf uang. } \\
\text { 1) Menggunakan } \\
\text { multipayment pada latform } \\
\text { perbankan ketika melakukan wakaf } \\
\text { uang guna mengembangkan } \\
\text { pariwisata halal di Kampung Al- } \\
\text { Munawar. } \\
\text { 2) Mengoptimalkan teknologi berbasis } \\
\text { website dan aplikasi bagi BWI pada } \\
\text { tingkat nasional dan daerah yang } \\
\text { mempromosikan pariwisata halal di } \\
\text { Kampung Al-Munawar. }\end{array}$ & \\
\hline & $\begin{array}{l}\text { Peningkatan } \\
\text { Kualitas Sumber } \\
\text { Daya Nazhir yang } \\
\text { profesional dan } \\
\text { berkompetensi }\end{array}$ & $\begin{array}{l}\text { 2.1. Memberlakukan sertifikasi bagi nazhir } \\
\text { yang mengelola Kampung Al- } \\
\text { Munawar. } \\
\text { 1) Memberlakukan regulasi yang } \\
\text { mewajibkan nazhir, baik } \\
\text { perseorangan maupun lembaga } \\
\text { untuk memiliki sertifikasi nazhir. }\end{array}$ & $\begin{array}{l}\text { Adanya nazhir yang memilki } \\
\text { sertifikasi dan profesional }\end{array}$ \\
\hline \multicolumn{2}{|c|}{$\begin{array}{l}\text { 3. Menjadikan wakaf } \\
\text { sebagai pendukung } \\
\text { Pariwisata Halal }\end{array}$} & $\begin{array}{l}\text { 3.1. Mengoptimalkan penyaluran dana wakaf } \\
\text { untuk mendukung usaha pelaku UMKM } \\
\text { yang bergerak pada industri halal } \\
\text { disekitar wilayah Kampung Al- } \\
\text { Munawar. } \\
\text { 1) Menyalurkan bantuan yang berasal } \\
\text { dari wakaf untuk mengembangkan } \\
\text { UMKM di sekitar Kampung Al- } \\
\text { Munawar. } \\
\text { 3.2. Memberdayakan aset wakaf untuk } \\
\text { produksi bagi industri halal, terutama } \\
\text { untuk produksi massal dan produksi yang } \\
\text { berorientasi ekspor di sekitar Kampung } \\
\text { Al-Munawar. } \\
\text { 1) Memberikan pelatihan kepada } \\
\text { masyarakat Kampung Al-Munawar } \\
\text { sehingga Kampung Al-Munawar } \\
\text { memiliki sentral oleh-oleh sendiri } \\
\text { yang memiliki perbedaan dengan } \\
\text { daerah lainnya. }\end{array}$ & $\begin{array}{l}\text { 1. Terciptanya penyaluran } \\
\text { dana wakaf untuk } \\
\text { mendukung usaha } \\
\text { pelaku UMKM yang } \\
\text { bergerak pada industri } \\
\text { halal disekitar wilayah } \\
\text { Kampung Al-Munawar } \\
\text { yang optimal. } \\
\text { 2. Kampung Al-Munawar } \\
\text { memiliki sentral oleh- } \\
\text { oleh sendiri yang } \\
\text { memiliki perbedaan } \\
\text { dengan daerah lainnya } \\
\text { melalui pemberdayaan } \\
\text { aset wakaf. }\end{array}$ \\
\hline & $\begin{array}{l}\text { Menjadikan pelaku } \\
\text { UMKM yang telah } \\
\text { menerima bantuan } \\
\text { dari dana } \text { wakaf } \\
\text { (mauquf 'alaih) }\end{array}$ & $\begin{array}{l}\text { 4.1. Memberikan pemahaman kepada pelaku } \\
\text { UMKM mengenai wakaf uang } \\
\text { 1) Melakukan sosialisasi } \\
\text { 2) Adanya pemindahan status dari } \\
\text { Mauquf alaih menjadi wakif }\end{array}$ & $\begin{array}{llr}\text { 1. } & \text { Pelaku } & \text { UMKM } \\
\text { memahami } & \text { dan } \\
\text { menjalankan wakaf uang }\end{array}$ \\
\hline
\end{tabular}


sebagai pemberi

waqaf (wa qif)

\section{Kesimpulan}

Dijadikannya Kampung Al-Munawar sebagai Objek Pariwisata pada tahun 2015 sebagai bentuk mensukseskan Asean Games, kampung AlMunawar memiliki beberapa kegiatan religi yang menjadi faktor dijadikannya kampung AlMunawar sebagai objek Pariwisata Halal sehingga pada tahun 2018 Kampung Al-Munawar dijadikan sebagai tempat wisata religi yang lebih dikenal sebagai Pariwisata Halal oleh Dinas Pariwisata dan Kebudayaan Provinsi Sumatera Selatan.

Kampung Al-Munawar Dijadikan sebagai tempat pariwisata halal tidak terlepas atas kerelaan masyarakat dalam merelakan tempat tinggal mereka sebagai tempat pariwisata halal yang dapat dikunjungi oleh banyak orang selama tidak terlepas dari ketentuan norma-norma agama Islam dan sosial di lingkungan masyarakat. Selain kerelaan dari masyarakat sekitar, berdirinya kampung almunawar sebagai kampung pariwisata menjadi salah satu peluang masyarakat kampung AlMunawar dalam mendapatkan sumber mata pencaharian masyarakat dilingkungan tersebut. Hal ini dikarenakan adanya status kampung AlMunawar sebagai kampung pariwisata.

\section{Daftar Pustaka}

Abu Abdullah Muhammad bin Muhammad bin Abdurrahman al-Hatab, (1329 H). Mawahib al-Jalil, Dar as-Sa'adah, Mesir, jilid 6, cet. I.

Aditha Maharani Ratna, Karakter Permukiman Islam Pada Kampung Arab Al Munawar di Palembang. Palembang: Program Studi Arsitektur, Fakultas Teknik.

Alim Sumarno, (2012). Penelitian Kausalitas Komparatif. Surabaya: Elearning Unesa.

Burhanuddin Ali bin Abu Bakar al-Murginani, $(1356 \mathrm{H})$, al-Hidayah, Mesir: Penerbit Mustafa Muhammad.
Mukhtar Lutfi, (2011). Optimalisasi Pengelolaan Wakaf. Makassar: Alauddin Press.

Hazami Bashlul, (2016). Peran dan Aplikasi Wakaf Dalam Mewujudkan Kesejahteraan Umat di Indonesia, Jurnal Analisis Volume XVI, Nomor 1, Juni 2016.

Ibn Himam, Fath al-Qadir, (1356 H). Mesir: Penerbit Mustafa Muhammad

Jaelani, A., Setyawan, E., \& Hasyim, N, (2016). Religious Heritage Tourism and Creative Economy in Cirebon: The Diversity of Religious, Cultures and Culinary. Journal of Social and Administrative Sciences, 3(1), 6376. Available at MPRA Paper No. 75181: https://mpra.ub.uni-muenchen.de/75181/. Diakses Pada 20/05/2019 di Palembang.

Kasdi Abdurrohman, (2017). Fikih Wakaf dari Wakaf Klasik hingga Wakaf Produktif. Yogyakarta: Idea Press.

Megawati Devi, (2014). Pengelolaan dan Pengembangan Wakaf Produktif di Kota Pekanbaru, Jurnal Hukum Islam, Vol. XIV No. 1 Nopember 2014. Pekanbaru: Jurnal Hukum Islam.

Mughniyah Muhammad Jawad, (2007). Fiqih Lima Mazhab, terj masykur a.b, Afif Muhammad \& Idrus Al-Kaff, Jakarta: Penerbit Lentera.

Mundzir Qahaf, (1995). Sanadât Al-Ijârah, AlMa'had Al-Islâmy li Al-Buhûts wa At-Tadrîb. Cairo: Dar as-Salam.

Saptono Teguh Imam dalam Repubika, (2019). Global Wakaf Ajak Masyarakat Berwakaf Sejak Dini, https://www.republika.co.id/berita/ekonomi/s yariah-ekonomi/17/10/13/oxroel440-globalwakaf-ajak-masyarakat-berwakaf-sejak-dini. Jakarta: Kantor Global Wakaf, Menara $165 \mathrm{Jl}$ TB Simatupang. Diakses pada 20/05/2019 di Palembang.

Setyowati Desy dalam Katadata.co.id, (2018). Transaksi Wisatawan Muslim Muda Diperkirakan $R p 2.700$ Triliun di 2026, https://katadata.co.id/berita/2018/10/19/transa ksi-wisatawan-muslim-muda-diperkirakanrp-2700-triliun-di-2026. Diakses pada 20/05/2019 di Palembang.

Subarkah Alwafi Ridho, (2018). Potensi Dan 
Prospek Wisata Halal Dalam Meningkatkan Ekonomi Daerah (studi kasus: nusa tenggara barat), jurnal sospol, vol 4.

Tholhah Hasan, (2009). Telaah Perkembangan Kebijakan Wakaf di Indonesia, http://www.antaranews.com. Diakses pada 20/05/2019 di Palembang

Tim Redaksi dalam Katadata.co.id, Potensi Besar Wisata Halal, https://katadata.co.id/infografik/2019/03/05/p otensi-besar-wisata-halal. Diakeses pada 20/05/2019 di Palembang.

UU No. 41 Tahun 2004 tentang Wakaf

Wahbah Zuhaili, (2008). al-fiqhu al-islami wa 'adillatuhu, damaskus: dar al-fikr almu'ashir 